\title{
THE FLU: AN ANALYSIS OF ECONOMIC COSTS AND MORBIDITY RATES IN POLAND IN THE PERIOD 2013-2019 USING ADAPTIVE PREDICTION METHODS
}

\author{
Monika Zielińska-Sitkiewicz ${ }^{\bowtie}$ \\ Warsaw University of Life Sciences - SGGW, Poland
}

\begin{abstract}
The flu is one of the most common human illnesses in the world. The number of infections is increasing year after year, and a flu pandemic could cause significant losses in the global economy. The aim of the study is to analyse the economic costs of the flu in Poland and to investigate the number of flu cases with the use of selected adaptive prediction methods. The research was conducted using monthly data collected by the National Institute of Public Health - National Institute of Hygiene for the period from January 2013 to December 2019. Three forecasting methods were used to perform the analyses: the moving average model, the Winters multiplicate model and the creeping trend model. The research results indicate that it is possible to use the creeping trend model to generate short-term prognoses for the flu. In addition, implementing programs to improve the effectiveness of flu prevention in Poland will help reduce the negative health, social and economic effects it creates.
\end{abstract}

Key words: flu, cost, prediction, creeping trend model

JEL codes: C53, H51, I15, I18

\section{INTRODUCTION}

The flu (short for influenza) is the most common infectious disease in Poland. Flu epidemics vary in severity every season and generate broad costs to the economy. The danger of viruses that spread rapidly and easily, and the severity of their financial and social costs, has been starkly displayed during the current COVID-19 pandemic. Every fall season, the number of flu cases increases exponentially, and the virus devastates not only organisms but also the economy. According to experts from Ernst \& Young, Poland loses about PLN 1.5 billion every year (at almost PLN 4 to USD 1, this equals USD 387 million), and during epidemic seasons this amount may increase to over PLN 4 billion (over USD 1 billion). The reduction of these costs is influenced by prevention, vaccinations and accurate prediction. The quality of morbidity predictions determines whether decisions based on the prognosis process can reduce the economic impact of viral diseases.

The aim of the study is to assess the economic costs of the flu and to analyse flu morbidity in Poland in the seasons from 2012/2014 to 2018/2019, using selected adaptive prediction methods to test their usefulness in predicting the disease.

Flu, as defined by the State Sanitary Inspectorate [Państwowa Inspekcja Sanitarna], is an acute respira- 
tory disease caused by the flu virus. It is transmitted mainly by direct contact with an infected person or with contaminated surfaces, and by droplets, when viruses are released in microparticles of secretions from the upper respiratory tract [Państwowa Inspekcja Sanitarna 2009]. The flu virus belongs to the class of RNA viruses and it has three types in humans:

- Type A is able to infect not only humans, but also other mammals and birds. This virus is responsible for the occurrence of repeated infections taking the form of an epidemic or a pandemic;

- Type B causes infections only in humans, which are mild, but can turn into more severe conditions;

- Type C, although it attacks quite often, mainly causes mild illnesses among children [Blank et al. 2016].

Flu viruses are microorganisms that rapidly undergo antigenic changes through the antigenic shift mechanism, i.e. spontaneous point mutations ("mistakes") in the process of viral replication. The frequency and ease of these changes causes annual epidemics of the disease because a past infection does not provide immunity.

The second way to create a new strain is gene reassortment (antigenic shift), which consists in mixing the genetic material of viruses of different strains. This situation occurs when one cell is attacked by two or more different viruses [Lifschitz 2011]. The resulting varieties are particularly dangerous because they can transmit new viruses to humans that previously infected only animals and vice versa. For example, in 1997, an avian influence virus labelled (A/H5N1) became dangerous to humans and received a new designation HPAI - "highly pathogenic avian influence virus". This type of gene shuffling is responsible for pandemics that occur every 10-50 years [Makowiec-Dyrda et al. 2016] - Table 1.

According to estimates by the World Health Organization, $5-10 \%$ of the adult population and $20-30 \%$ of children are infected with the flu virus worldwide each year. Acute disease symptoms are registered in 3-5 million people. Flu epidemics cause between 290,000 and 650,000 deaths globally and an average of 38,500 deaths in Europe. Type A viruses (mainly $\mathrm{A} / \mathrm{H} 1 \mathrm{~N} 1$ and $\mathrm{A} / \mathrm{H} 3 \mathrm{~N} 2$ ) may cause a pandemic as a result of an antigenic jump, while type $B$ viruses cause an epidemic every 2-4 years [Antczak et al. 2017].

Flu is a notifiable disease to the National Institute of Public Health - National Institute of Hygiene (Narodowy Instytut Zdrowia Publicznego - Państwowy Zakład Higieny). Epidemiological data is related to the number of influenza and influenza-like illnesses and is collected by the Department of Epidemiology and Surveillance of Infectious Diseases (Zakład Epidemiologii Chorób Zakaźnych i Nadzoru). This data show quite different levels over the last ten years and, according to experts, indicates a clear underestimation of the problem due to the limited number of cases that are actually reported. Flu is usually self-limiting and is treated on an outpatient basis. The diagnosis of flu is made primarily on the basis of clinical symptoms, and virus identification tests are seldom ordered. In Poland, in recent years, the incidence of flu has ranged from 7,332 to 13,888 cases per 100,000 per season, which gives an average of about 4 million registered cases per season (from October to September) - Figure 1.

Table 1. Major flu pandemics of the 20th century

\begin{tabular}{lcc}
\hline Period & Virus strain & Estimated number of deaths \\
\hline $1918-1919$ & Spanish flu (A/H1N1) & $50-100$ million \\
\hline $1957-1958$ & Asian flu (A/H2N2) & $1-4$ million \\
\hline $1968-1970$ & Hong Kong flu (A/H3N2) & $1-4$ million \\
\hline
\end{tabular}

Source: Ernst \& Young et al. [2003], WHO [2009a, b]. 


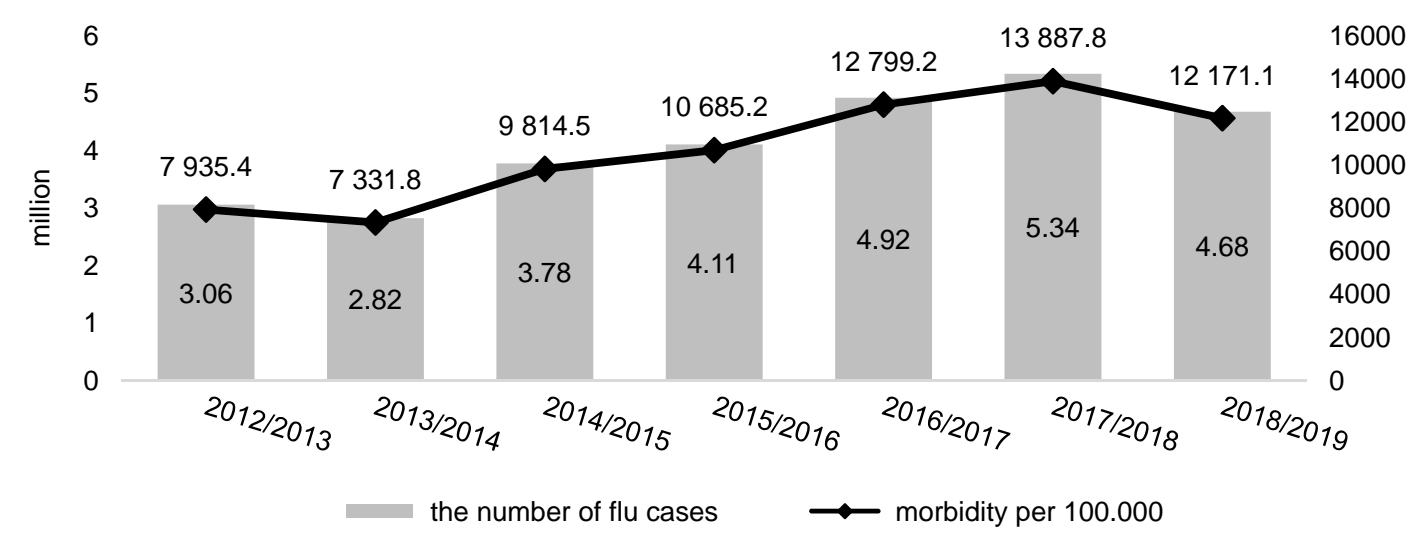

Fig. 1. The number of flu cases and morbidity per 100,000 in Poland

Source: Author's presentation based on National Institute of Public Health - National Institute of Hygiene data.

\section{THE ECONOMIC ASPECT OF INFLUENZA}

The flu not only wreaks havoc on the body, it also negatively affects the economy. The amount that Poland loses from influenza depends, of course, on the number of sick people, but there are also other factors. The economic problem of the flu was analysed by Ernst \& Young, which - in cooperation with the National Institute of Public Health - National Institute of Hygiene, the Institute for Flu Research (Zakład Badania Wirusów), the National Flu Centre (Krajowy Ośrodek ds. Grypy) and the Polish Society for Health Education (Polskie Towarzystwo Oświaty Zdrowotnej) - undertook the task of estimating the cost of the flu in Poland and publishing a special report.

The costs associated with the onset of the disease have been divided into three main types:

- Direct costs, understood as all inputs incurred as the result of a medical intervention or treatment of a given disease unit. Direct costs are relatively the most easily identifiable cost category, which allows for relatively accurate estimation of their value. This group includes the costs of: treatment (symptomatic), medical visits, treatment of complications after flu, specialist examinations and hospitalization.

- Indirect costs, i.e. loss of productivity resulting from illness, in particular: costs of absenteeism or long-term absence from work due to one's own ill- ness or to care for a sick person, and a decrease in the work efficiency of sick people who are not on sick leave.

- Intangible costs, which are difficult to describe in economic terms, such as: deterioration of the quality of life (e.g. due to pain), loss of free time, limited possibilities of functioning (e.g. social activity).

In the report, direct costs were estimated on the basis of available National Health Fund (Narodowy Fundusz Zdrowia) data on expenses for the treatment of flu itself, some complications, estimates of the valuation of services in primary healthcare facilities, and a basket of medications for flu constructed by experts, along with the most common complications of respiratory diseases. For the year without an epidemic, direct costs amounted to approximately PLN 43.5 million, and were nearly PLN 730 million in the scenario for the year with an epidemic. However, indirect costs in the year without an epidemic were estimated at about PLN 836 million, while reaching PLN 4,302 million in the year with an epidemic [Ernst \& Young et al. 2013].

In total, over $60 \%$ of indirect costs are related to absenteeism or reduced productivity. This is due, in part, to the high reliance on labour productivity found in the economies of less-developed countries, such as Poland. The absence of an employee (estimated cost - PLN 286 million - Fig. 2) or his/her lower efficiency (estimated cost - PLN 280 million - Fig. 2) strongly affects the financial results of companies and the entire 


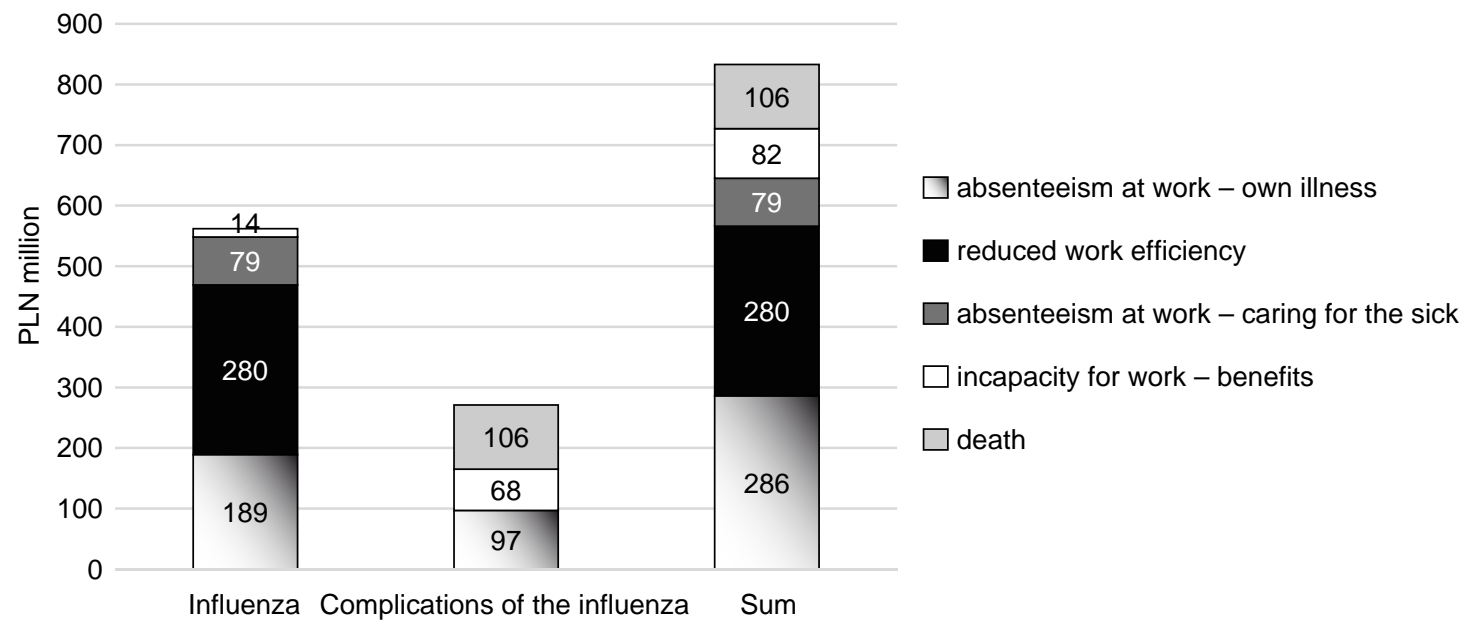

Fig. 2. Share of individual cost groups in total flu costs - indirect costs (season without epidemics)

Source: Ernst \& Young et al. [2013].

economy, which can be seen in the current COVID-19 pandemic.

It may be argued whether these economic cost estimates for flu are overestimated, as the National Institute of Public Health - National Institute of Hygiene data on which the report is based includes both flu cases and suspected flu cases. However, it is obvious that the flu generates a range of costs for the economy, and the amounts presented in the report are impressive.

The Ernst \& Young analysis clearly indicates that prevention and raising the number of vaccinations are measures that reduce the financial burden on the economy. The effectiveness of vaccines for the entire population depends significantly on the scope of the vaccination program, and unfortunately, in Poland only $3-5 \%$ of Poles are vaccinated against the flu. For comparison, in the Netherlands and the United Kingdom, the vaccination coverage level in the population is close to $75 \%$. According to experts, the optimal level of vaccination that maximizes savings is around $45 \%$ and in a season without a flu epidemic may bring savings of PLN 500 million (almost 70\% of costs) [Ernst $\&$ Young et al. 2013]. Taking into account the current costs of the vaccine (about PLN 30), this is the same amount that the government would have to spend on the purchase of vaccines for over 17 million citizens. However, when considering a widespread epidemic season, and potential savings of PLN 3 billion, the amount of expenditure on vaccines does not seem so high, especially as it would greatly contribute to the underlying health and quality of life for the country's population and economy.

\section{ADAPTIVE PREDICTION METHODS}

Adaptive forecasting models are characterised by high flexibility and adaptability in the case of irregular changes in the direction or speed of the trend or distortions in periodic fluctuations. It makes adaptive models a convenient tool for short-term economic forecasts [Zeliaś et al. 2003].

In the study of the possibility of predicting the number of flu cases, after the graphical analysis of the data and taking into account the observed seasonality, the following prognostic methods were used: unweighted moving average with $k=3$, Winters multiplicative model and creeping trend model with $k=3$.

The moving average and the Winters methods are widely described in the literature on the subject [Zeliaś et al. 2003, Cieślak 2005]. The crawling trend model was introduced by Z. Hellwig [1970] following the principle characteristic of adaptive methods - greater impact on the forecast value from newer data than from older data. The creeping trend is used to describe the shaping of a phenomenon characterised by irregular fluctuations, such as the number of flu cases. 
The procedure of determining the creeping trend consists of smoothing the time series $y_{1}, \ldots, y_{n}$ with an arbitrarily selected smoothing constant $k$, so that random fluctuations are eliminated. The linear trend equations are determined using the method of least squares on the basis of $k$ successive observations, i.e. the parameters of $n-k+1$ segmental equations are estimated as:

$$
\begin{gathered}
\hat{y}_{t j}=a_{0 j}+a_{1 j} t \\
(j=1, \ldots, n-k+1, t=j, \ldots, j+k-1)
\end{gathered}
$$

where:

$k-$ smoothing constant is the number of cases for each partial trend,

$j \quad-$ number of partial trend equation,

$\hat{y}_{t j}$ - determined smoothed value; for a given $t$ from 2 to $n-1$, there is a set of approximants calculated from the partial trend equations,

$a_{0 j}, a_{1 j}$ - estimated values of the partial trend equations.

The creeping trend is computed according to the formula

$$
\hat{y}_{t}=b_{0 t}+b_{1 t} t
$$

and the following calculation can be used to obtain the estimates:

$$
\begin{aligned}
& b_{0 t}=\frac{1}{m} \sum_{j=j_{0}}^{j_{0}+m-1} a_{0 j} \\
& b_{1 t}=\frac{1}{m} \sum_{j=j_{0}}^{j_{0}+m-1} a_{1 j}
\end{aligned}
$$

where:

$\hat{y}_{t}-$ determined smoothed value (fitted value) for period $t$,

$b_{0 t}, b_{1 t}$ - estimated values being mean values of estimates of the partial trend equations for $t \in\langle j, j+k-1\rangle$,

$m$ - number of the partial trend equations for $t \in\langle j, j+k-1\rangle$,

$j_{0}-$ number of the first partial trend equation for $t \in\langle j, j+k-1\rangle$.
By combining successive points $\left(t, \hat{y}_{t}\right)$, the development trend of the time series is obtained in the form of a segment, the so-called creeping trend. Let us note the series of predictions is exactly the same length as the output series of real observations.

\section{RESULTS OF THE STUDY}

The data used in the study come from the Laboratory of Monitoring and Epidemiological Analysis (Pracownia Monitorowania i Analizy Sytuacji Epidemiologicznej) located in the Department of Epidemiology and Surveillance of Infectious Diseases, which is part of the National Institute of Public Health - National Institute of Hygiene. The time series included observations corresponding to the number of cases in the months from January 2013 to December 2019.

In order to check the suitability of the following models: the unweighted moving average model with $k=3$, the Winters multiplicative model and the creeping trend model with $k=3$ for short-term prediction of the number of flu cases, their accuracy was tested by preparing expired forecasts for 2013-2019. The analysis of ex post errors was used to determine the admissibility of forecasts; moreover, it was assumed that the length of the verification interval for expired forecasts will be seven years. The comparison of the predicted disease values for the past with the observed actual values for the same period allowed for the formulation of conclusions as to the usefulness of the three prediction algorithms used. Moreover, it provided the basis for determining the scale of error between the forecasts and the actual state of cases.

Figures 3 and 4 show the actual and forecast numbers of flu cases obtained by the moving average model and the Winters multiplicative model, respectively.

On the basis of Figures 3 and 4, it can be concluded that the two selected adaptation models did not work well in terms of a good adjustment of forecasts to actual data. The values of standard deviations of the RMSE forecast errors and the MAE absolute errors prove that the obtained predicted numbers of flu cases strongly deviate from the actual values, and the MAPE error levels indicate that the forecasts are not acceptable. Figure 5 presents the actual incidence and expired forecasts obtained from the creeping trend model. 


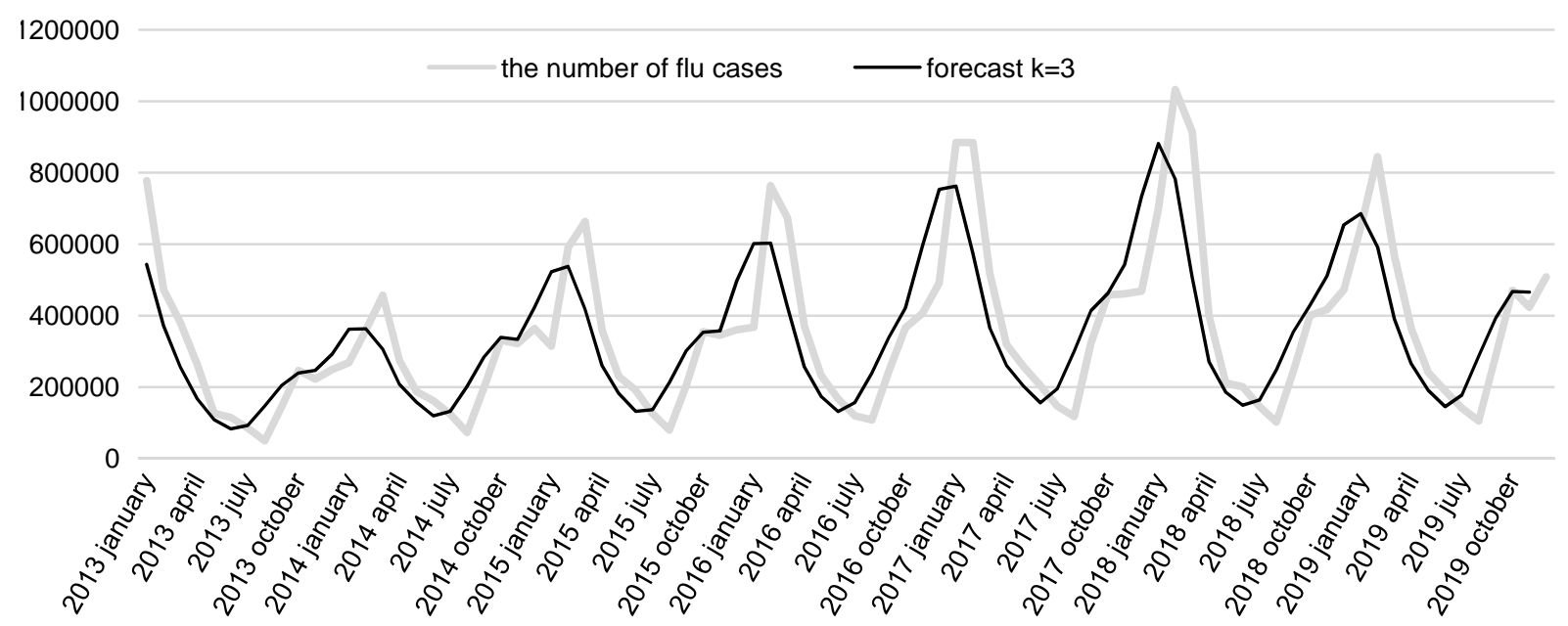

Fig. 3. Real and forecast number of flu cases - the moving average model with smoothing constant $k=3$ Source: Author's calculations.

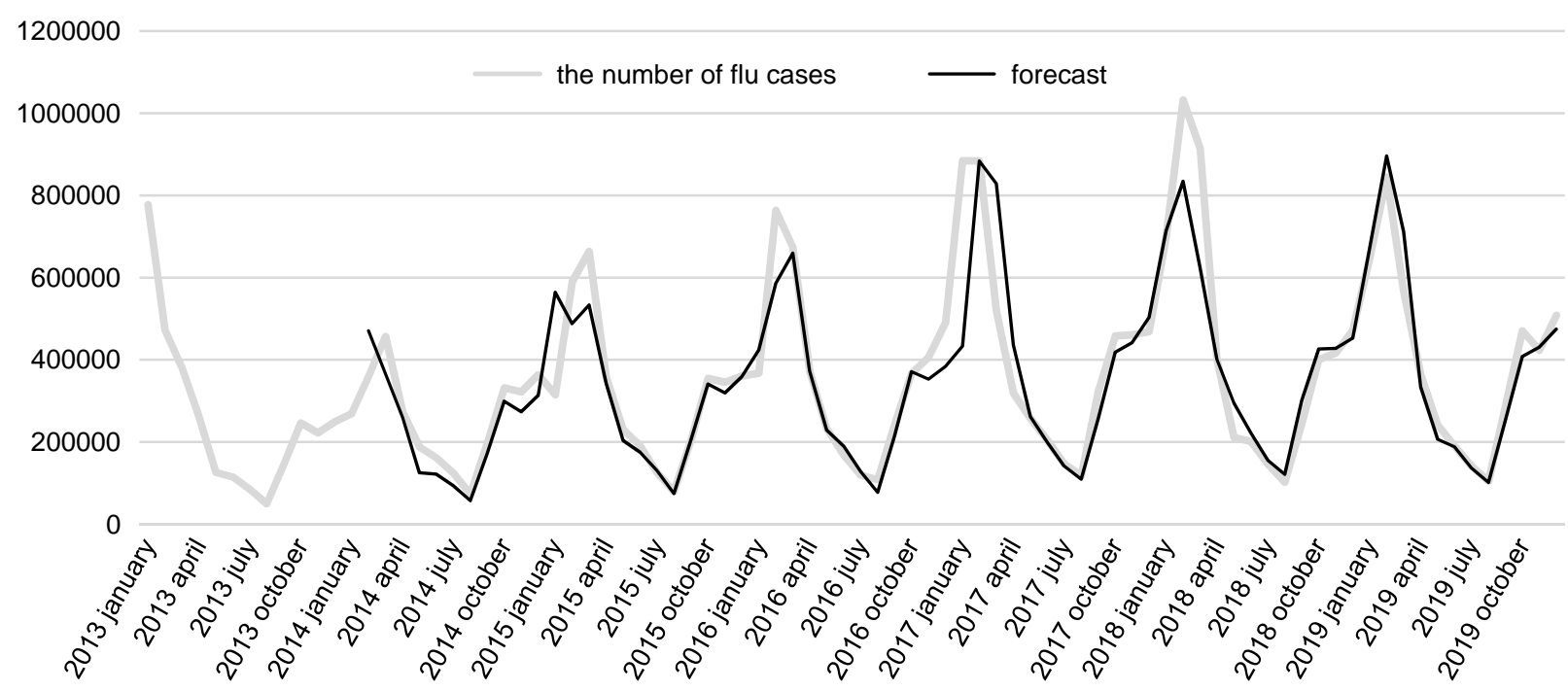

Fig. 4. Real and forecast number of flu cases - the Winters multiplicative model Source: Author's calculations.

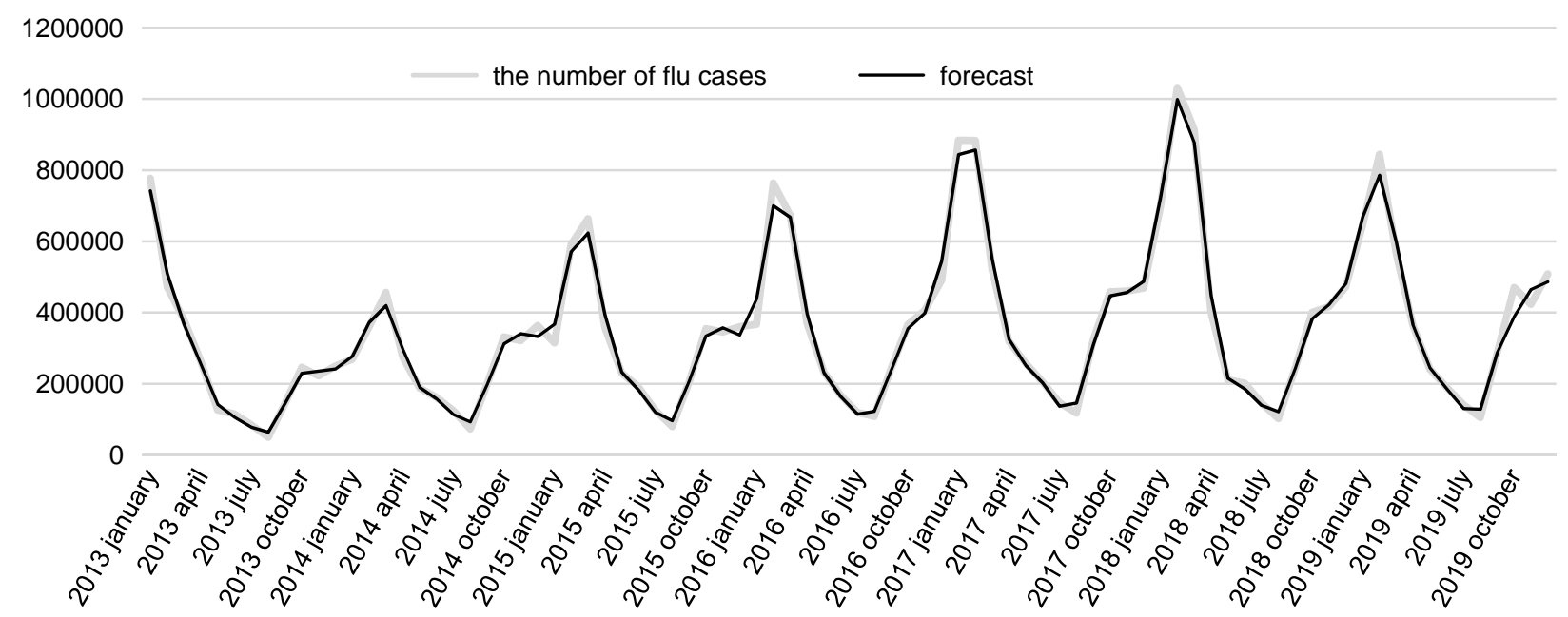

Fig. 5. Real and forecast number of flu cases - the creeping trend model with smoothing constant $k=3$ Source: Author's calculations. 
The crawling trend model with greater weight takes into account observations closer to the forecast values, which has worked well for quite large distortions of random fluctuations in the number of flu cases.

The values of standard deviations of the RMSE forecast errors and the $M A E$ absolute errors indicate that the forecasts of the number of flu cases differ from the actual levels by about 20,000 infection cases. The MAPE value allows for the recognition of expired forecasts as acceptable and almost accurate (Table 2). confirms the threats described in the report - reduced labour supply, limited economic activity, lower tax revenues and increased state spending, and consequently growing public debt. The government should take measures to raise public awareness of the key role of hygiene in public health, the increased risk of epidemics in the modern globalised world and the importance of flu prevention. Flu vaccination coverage in Poland is alarmingly low at $3-4 \%$. The threats or negative side effects resulting from vaccination are

Table 2. Values of the different accuracy measures

\begin{tabular}{lccc}
\hline Forecast model & RMSE & MAE & MAPE (\%) \\
\hline Moving average model with $k=3$ & 59684.81 & 42387.69 & 14.73 \\
\hline Winters multiplicative model & 89544.16 & 43614.02 & 9.75 \\
\hline Creeping trend model with $k=3$ & 25641.93 & 19040.62 & 5.15 \\
\hline
\end{tabular}

Source: Author's calculations.

\section{CONCLUSIONS}

In forecasting the number of flu cases in Poland, the best results, understood as the lowest values of the average relative errors of ex-post forecasts, were obtained for forecasts determined using the crawling trend model with short segments $(k=3)$. This result can be explained by a good adaptation of the method to the variability of the studied phenomenon, which was characterised by irregularities and trend breaks. The effects of the crawling trend model with linear regression turned out to be satisfactory and may suggest the usefulness of this method for short-term prediction of the number of flu cases as a supplement to the epidemiological models already used. However, the presented results should not be treated arbitrarily, because in the case of a different type of time series with a different course, trend breaks and a large share of random fluctuations, better results can be obtained using other models.

The analysis of the economic costs of the flu from the Ernst \& Young report reveals their scale and consequences for the economy. The current coronavirus pandemic, severely affecting society as a whole, not confirmed by countries with very high vaccination coverage of the flu, on the order of $75 \%$ - such as Great Britain or the Netherlands. And at the level of $22 \%$ of vaccination coverage, the Polish economy can achieve benefits of PLN 100 million, not to mention the positive health effects. It should be remembered that due to the ease of spreading the flu virus, its frequent mutations, as well as non-specific clinical symptoms and the risk of developing health and life-threatening complications after the flu, flu epidemics and pandemics pose a significant social danger.

\section{REFERENCES}

Antczak, A., Jahn-Różyk, K., Krzywański, J., Kuchar, E., Mastalerz-Migas, A., Nitsch-Osuch, A., Szenborn, L. (2017). Rekomendacje ekspertów Krajowego Programu Zwalczania Grypy dotyczące profilaktyki grypy w sezonie epidemicznym 2017/2018. Fundacja Nadzieja dla Zdrowia, Warszawa.

Blank, P., Falup-Pecurariu, O., Kassianos, G., Kuchar, E., Kyncl, J., Nitsch-Osuch, A., Van Essen, T. (2016). Szczepienia przeciw grypie: podstawowe fakty dla lekarzy pierwszego kontaktu w Europie Synteza opracowana przez ekspertów europejskich na podstawie zaleceń 
krajowych i najlepszych praktyk w Wielkiej Brytanii i Holandii. Fundacja Nadzieja dla Zdrowia, Warszawa.

Cieślak, M. (Ed.) (2005). Prognozowanie gospodarcze. Metody i zastosowania. Wydawnictwo Naukowe PWN, Warszawa.

Ernst \& Young et al. (2013). Grypa i jej koszty. Wstępne studium w projekcie dotyczącym wypracowania rozwiązania na poziomie narodowym umożliwiającego istotne zwiększenie wyszczepialności przeciw grypie sezonowej w Polsce. Raport. Ernst \& Young, Narodowy Instytut Zdrowia Publicznego - PZH, Zakład Badania Wirusów Grypy, Krajowy Ośrodek ds. Grypy, Polskie Towarzystwo Oświaty Zdrowotnej, Grupa Robocza ds. Grypy, Kancelaria Domański Zakrzewski Palinka, Warszawa.

Hellwig, Z. (Ed.) (1970). Zarys ekonometrii. PWE, Warszawa.

Lifschitz, C. (2011). Influenza - facts and treatments. Medical Standards/Paediatrics, 5, 703-710.
Makowiec-Dyrda, M., Windak, A., Tomasik, T., Kochan, P., Drzewiecki, A., Garlicki, A., Lukas, W., Horst-Sikorska, W., Buczkowski, K., Chlabicz, S. (2016). Profilaktyka i leczenie grypy. Wytyczne Kolegium Lekarzy Rodzinnych w Polsce. Kolegium Lekarzy Rodzinnych w Polsce, Łódź.

Państwowa Inspekcja Sanitarna (2009). Treści merytoryczne i metodyczne dotyczące zapobiegania grypie sezonowej i nowej grypie A(H1N1)v. Główny Inspektorat Sanitarny, Department Zdrowia Publicznego i Promocji Zdrowia, Warszawa.

World Health Organization - WHO (2009a). Implementation of the international health regulations in relation to pandemic (AH1N1). World Health Organization, Geneva.

World Health Organization - WHO (2009b). Pandemic influenza preparedness and response: a WHO guidance document. World Health Organization, Geneva.

Zeliaś, A., Pawełek, B., Wanat, S. (2003). Prognozowanie ekonomiczne. Wydawnictwo Naukowe PWN, Warszawa.

\section{EKONOMICZNE KOSZTY GRYPY I ANALIZA ZACHOROWALNOŚCI NA GRYPĘ W POLSCE W LATACH 2013-2019 Z WYKORZYSTANIEM ADAPTACYJNYCH METOD PREDYKCJI}

\section{STRESZCZENIE}

Grypa jest jedną z najczęstszych przyczyn zachorowalności ludzi na świecie. Liczba infekcji z roku na rok jest coraz większa a potencjalna pandemia może spowodować znaczące straty w światowej gospodarce. Celem opracowania jest analiza ekonomicznych kosztów grypy oraz zbadanie liczby zachorowań na grypę w Polsce z wykorzystaniem wybranych adaptacyjnych metod predykcji. Badania przeprowadzono, wykorzystując dane miesięczne gromadzone przez Narodowy Instytut Zdrowia Publicznego - Państwowy Zakład Higieny z okresu od stycznia 2013 roku do grudnia 2019 roku. Do wykonania analiz wykorzystano trzy metody prognozowania: model średniej ruchomej, multiplikatywny model Wintersa oraz model trendu pełzajacego. W świetle wyników badań okazało się, że jest możliwe wykorzystanie modelu trendu pełzajacego do generowania krótkoterminowych prognoz zachorowań na grypę. Ponadto wdrażanie programów poprawiających efektywność profilaktyki grypy w Polsce pomoże ograniczać jej zdrowotne, społeczne i ekonomiczne.

Słowa kluczowe: grypa, koszt, predykcja, trend pełzający 